\title{
PEMBAGIAN KEKUASAAN ANTARA MPR, DPR, DAN DPD DALAM MEWUJUDKAN SISTEM KETATANEGARAAN YANG BERKEDAULATAN RAKYAT
}

\author{
Oleh: Drs Munif Rochmawanto, SH, MH, MM
}

\begin{abstract}
Abstrak
Berdasarkan Undang-Undang Dasar Negara Republik Indonesia Tahun 1945 sebelum amandemen, sistem parlemen di Indonesia adalah satu kamar (monocameral), meski terdapat dua badan perwakilan yaitu Majelis Permusyawaratan Rakyat (MPR) dan Dewan Perwakilan Rakyat (DPR). Dalam sistem parlemen ini kekuasaan legislasi diletakkan kepada DPR bersama-sama Presiden. Seiring dengan perkembangan sistem ketatanegaraan Indonesia, berdasarkan amandemen Undang-Undang Dasar Negara Republik Indonesia Tahun 1945 sistem satu kamar tersebut berubah menjadi sistem parlemen dua kamar (bicameral), yang terdiri dari Dewan Perwakilan Rakyat (DPR) dan Dewan Perwakilan Daerah (DPD). Hal ini berarti bahwa kekuasaan legislasi berada di tangan Dewan Perwakilan Rakyat (DPR) dan Dewan Perwakilan Daerah (DPD).

Perubahan mendasar terjadi pada Pasal 1 ayat (2) yang sebelumnya berbunyi "Kedaulatan di tangan rakyat dilakukan sepenuhnya oleh Majelis Permusyawaratan Rakyat", berubah menjadi "Kedaulatan Rakyat berada di tangan rakyat dan dilaksanakan menurut Undang-Undang Dasar". Perubahan yang sangat mendasar terhadap Pasal 1 ayat (2) telah menimbulkan reaksi keras dari Gerakan Nurani Parlemen, Forum Kajian Ilmiah Konstitusi, sekelompok purnawirawan ABRI dan akademisi yang menentang rumusan itu. Mereka menilai perubahan itu telah mengubah dasar "Kerakyatan yang dipimpin oleh hikmat kebijaksanaan dalam pennusyawaratan atau perwakilan", dan meniadakan eksistensi MPR sebagai lembaga tertinggi negara sebagai pemegang kedaulatan rakyat. Tetapi pandangan tersebut ditolak oleh sebagaian kelompok lain, bahwa eksistensi MPR tidak akan hilang tetapi berubah fungsi sebagai forum, dan bukan lagi sebagai lembaga. Karena forum, maka MPR tidak perlu lembaga, tetapi hanya merupakan sidang gabungan (joint sesion) antara DPR dan DPD, yang dirumuskan dalam pasal 2 (Rancangan perubahan Keempat). MPR mengubah diri sebagai parlemen bicameral.
\end{abstract}

\section{Kata Kunci : Pembagian Kekuasaan, Sistem Ketatanegaraan, Berkedaulatan Rakyat}

\section{A. Pendahuluan}

1. Latar Belakang Masalah

Melalui sidang MPR yang dimulai tahun 1999 telah berhasil dilakukan perubahan (amandemen) terhadap Undang-Undang Dasar Negara Republik Indonesia Tahun 1945. Perubahan ini telah menimbulkan berbagai pergeseran dan reformasi dalam beberapa hal terkait dengan struktur, fungsi lembaga-lembaga negara, sistem pemerintahan dan lain-lain.

Berdasarkan Undang-Undang Dasar Negara Republik Indonesia Tahun 1945 sebelum amandemen, sistem parlemen di Indonesia adalah satu kamar (monocameral), meski terdapat dua badan perwakilan yaitu Majelis Permusyawaratan Rakyat (MPR) dan Dewan Perwakilan Rakyat (DPR). Dalam sistem parlemen ini kekuasaan legislasi diletakkan kepada DPR bersama-sama Presiden. Seiring dengan perkembangan sistem ketatanegaraan Indonesia, berdasarkan amandemen UndangUndang Dasar Negara Republik Indonesia Tahun 1945 sistem satu kamar tersebut berubah menjadi sistem parlemen dua kamar (bicameral), yang terdiri dari Dewan Perwakilan Rakyat (DPR) dan Dewan Perwakilan Daerah (DPD). Hal ini berarti bahwa kekuasaan legislasi berada di tangan Dewan Perwakilan Rakyat (DPR) dan Dewan Perwakilan Daerah (DPD).

Pengertian sederhana dari sistem perwakilan bicameral adalah lembaga perwakilan yang terdiri dari dua kamar. Menyangkut sistem perwakilan dua kamar (bicameral) sebagaimana diatur dalam ketentuan amandemen Undang-Undang Dasar Negara Republik Indonesia Tahun 1945, beberapa ahli memberikan pendapat mengenai hal tersebut. Hal ini terkait dengan keberadaan MPR sebagai salah satu 
badan perwakilan yang masih memiliki kewenangan tersendiri dan kewenangan yang dimiliki oleh Dewan Perwakilan Daerah.

$$
\text { Perubahan mendasar terjadi }
$$
pada Pasal 1 ayat (2) yang sebelumnya berbunyi "Kedaulatan di tangan rakyat dilakukan sepenuhnya oleh Majelis Permusyawaratan Rakyat", berubah menjadi "Kedaulatan Rakyat berada di tangan rakyat dan dilaksanakan menurut Undang-Undang Dasar”. Perubahan yang sangat mendasar terhadap Pasal 1 ayat (2) telah menimbulkan reaksi keras dari Gerakan Nurani Parlemen, Forum Kajian Ilmiah Konstitusi, sekelompok purnawirawan ABRI dan akademisi yang menentang rumusan itu. Mereka menilai perubahan itu telah mengubah dasar "Kerakyatan yang dipimpin oleh hikmat kebijaksanaan dalam pennusyawaratan atau perwakilan", dan meniadakan eksistensi MPR sebagai lembaga tertinggi negara sebagai pemegang kedaulatan rakyat. Tetapi pandangan tersebut ditolak oleh sebagaian kelompok lain, bahwa eksistensi MPR tidak akan hilang tetapi berubah fungsi sebagai forum, dan bukan lagi sebagai lembaga. Karena forum, maka MPR tidak perlu lembaga, tetapi hanya merupakan sidang gabungan (joint sesion) antara DPR dan DPD, yang dirumuskan dalam pasal 2 (Rancangan perubahan Keempat). MPR mengubah diri sebagai parlemen bicameral. $^{1}$

Hingga kini perwujudan sistem perwakilan di Indonesia dalam bentuk MPR, memberikan kesan Indonesia menganut sistem unicameral berciri bicameral. Ciri bicameral tak cukup tampak karena kamar yang lain tidak memiliki fungsi tersendiri dan tidak melembaga. Watak unicameral ini makin menonjol saat 60 persen keangotaan MPR diisi DPR (500 orang), sehingga MPR kini hanya "DPR luas". Maka pendapat "unicameral berciri bicameral"

1 Ni'matul Huda, Teori dan Hukum Konstitusi, PT. RajaGrafindo, Jakarta, 2003 hal 35. (atau campuran keduanya) tak cukup menyakinkan untuk menjelaskan watak parlemen Indonesia. Banyak pihak lantas menggunakan istilah "Sistem MPR" bagi sistem perwakilan di Indonesia. ${ }^{2}$.

Menurut Jimly Asshiddiqie, struktur parlemen kita pasca perubahan keempat tidak tepat untuk disebut sebagai parlemen dua kamar sesuai prinsip "strong bicameral". Sistem yang kita anut paling jauh hanya dapat disebut sebagai "soft bicameral" karena kedudukan dua kamar DPR dan DPD itu tidak Namun, karena MPR sendiri juga tidak dapat disebut hanya sebagai "joint session" antara DPR dan DPD, maka bangunan parlemen kita juga tidak dapat disebut sebagai "soft bicameral" sekalipun. ${ }^{3}$ Dari kedua pandangan tersebut di atas dapat dikatakan bahwa Indonesia tidak mengadopsi sistem perwakilan dua kamar dalam pengertian yang sebenarnya. Sebagai lembaga perwakilan Rakyat, DPR dan DPD adalah lembaga legislator yang bertugas untuk membuat undang-undang. Namun antara kedua lembaga ini memiliki bidang kekuasaan yang berbeda. Perbedaannya dapat dilihat dari kekuasaan DPR untuk membuat semua bentuk undang-undang termasuk dalam bidang otonomi daerah yang merupakan kewenangan dari DPD. Kewenangan dari DPD dalam bidang legislasi hanya terbatas pada bidang-bidang tertentu seperti dalam bidang otonomi, hubungan pusat dan daerah pembentukan dan pemekaran, dan penggabungan daerah, pengelolaan sumber daya alam, dan sumber daya ekonomi lainnya yang berkaitan dengan perimbangan pusat dan daerah.

Lebih lanjut menyangkut kekuasaan-kekuasaan dari DPR dan DPD, kekuasaan yang dimiliki oleh DPD terlebih dahulu harus diusulkan kepada

\footnotetext{
${ }^{2}$ Ibid hal 36).
}

3 Jimly Asshidiqie. Format kelembagaan Negara dan Pergeseran Kekuasaan dalam UUD 1945. Yogyakarta : FH UII Press. 2004 hal. 13. 
DPR untuk kemudian dibahas bersamasama. Sedangkan dalam hal pembuatan undang-undang oleh DPR, secara legal konstitusi tidak ada keharusan bagi DPR untuk mengkoordinasikannya atau mengkonsultasikannya terlebih dahulu kepada DPD.

Kenyataan dari pengaturan sebagaimana tersebut di atas, legalitas terhadap kekuasaan yang diberikan oleh peraturan perundang-undangan terhadap kekuasaan DPR dan DPD sepertinya tidak mencerminkan nilai-nilai demokrasi yang seutuhnya. DPD sebagai bagian dari kekuasaan lembaga legislatif yang terpilih melalui pemilihan umum langsung oleh rakyat diamanatkan untuk membawa nilai-nilai aspirasi dari rakyat sesuai porsi dan kewenangan keberadaanya. Hal ini di maksudkan agar kedaulatan tersebut dapat terwujud secara utuh, sesuai dengan aspirasi dan cita-cita masyarakat Indonesia.

Selain itu, pembentukan DPD yang dimaksudkan agar terciptanya suatu kondisi yang parlemen khususnya dan kekuasaan pada umumnya yang saling mengawasi dan mengimbangai (check and balance) adalah juga merupakan sarana bagi terwujudnya parlemen yang demokratis.

Oleh karenanya, sebagai negara yang mengakui kedaulatan rakyat sebagai dasar dalam menjalankan kehidupan berbangsa dan bernegara seyogyanya pembentukan sistem parlemen 2 (dua) kamar di Indonesia yang terdiri dari DPR dan DPD dapat mencerminkan dua unsur perwakilan yang sebenarnya.

\section{Rumusan Masalah}

Berdasarkan latar belakang
masalah tersebut diatas, penulis
mengetengahkan dua permasalahan
yanitu:

a. Bagaimanakah pembagian kekuasaan antara MPR, DPR dan DPD dalam mewujudkan sistem ketatanegaraan yang berkedaulatan rakyat?

b. Bagaimanakah hubungan antara MPR, DPR dan DPD dalam sistem dalam ketatanegaraan di Indonesia setelah amandemen Undang-Undang Dasar RI Tahun 1945 ?

\section{Tujuan Penelitian}

a. Untuk mengetahui bagaimana pembagian kekuasaan antara MPR, DPR dan DPD dalam mewujudkan sistem ketatanegaraan yang berkedaulatan rakyat.

b. Untuk mengetahui bagaimana hubungan antara MPR, DPR dan DPD dalam sistem dalam ketatanegaraan di Indonesia setelah amandemen UUD 1945.

\section{B. Kajian Teori}

1. Lembaga Perwakilan Dengan Sistem Monocameral

Lembaga legislatif atau biasa disebut parlemen adalah lembaga yang mewakili dan menampung aspirasi rakyat. Sebagai konsekuensi dari prinsip negara yang berbasis pada kedaulatan rakyat, maka keanggotaan legislatif seyogyanya dipilih langsung oleh rakyat yakni melalui pemilihan langsung. Sesuai namanya legislatif, adalah lembaga tinggi negara yang fungsi utamanya adalah membuat Undangundang, karena legislatif adalah kumpulan dari berbagai aspirasi (aspirasi idiologi maupun aspirasi kewilayahan) maka tidak bisa dihindari terjadinya perdebatan sengit antar anggota karena masing-masing memperjuangkan aspirasinya agar bisa "mewarnai" Undang-undang. Legislatif juga berfungsi sebagai pengawas kegiatan eksekutif (lembaga pelaksana Undangundang). Dalam sistem parlementer lembaga legislatif memilih dan menetapkan kepala pemerintahan. Di Indonesia lembaga legislatif dikenal dengan nama Dewan Perwakilan Rakyat (DPR) atau sistem satu kamar (Unicameral) sistem satu kamar ini dijalankan oleh Indonesia sebelum terjadinya perubahan Undang-undang Dasar 1945. Sistem satu kamar ini dilambangkan dengan adanya MPR sebagai pemegang kedaulatan rakyat, dimana keanggotaan dari MPR termasuk didalamnya adalah anggota-anggota DPR. 
Sistem satu kamar biasa dipilih oleh negara yang masyarakatnya dinilai homogen dengan luas wilayah yang relatif tidak terlalu besar. Seluruh anggoata parlemen (wakil rakyat) berada dalam satu kamar. Proses keanggotaan parlemen dilakukan lewat pemilihan umum, dicalonkan oleh partai, minimal memenuhi persyaratan untuk mendapatkan kursi di parlemen. Dalam pemilihan umum partai-partai yang diperankan oleh kader-kadernya bersaing untuk mendapatkan dukungan dan simpati rakyat atas idiologi dan atau konsep membangun negara yang ditawarkan dan atau konsep mensejahterakan rakyat dalam skala nasional aspirasi rakyat sepenuhnya diwakili oleh partai-partai.

\section{Lembaga Perwakilan Dengan Sistem Bicameral}

Satu hal yang perlu diketahui, sistem satu atau dua kamar tidak terikait dengan satu landasan bernegara tertentu, dan juga tidak terkait dengan bentuk negara, bentuk pemerintahan atau sistem pemerintahan tertentu. Setiap negara mempunyai pertimbangan sendirisendiri. Ada negara yang menjalankan sistem dua kamar karena latar belakang kesejarahan.

Inggris menjalankan sistem dua kamar, antara lain untuk memelihara kehadiran perwakilan kaum bangsawan disamping rakyat umum. Sistem dua kamar di Inggris tidak terlepas dan proses demokratisasi badan perwakilan. Semula badan perwakilan Inggris hanya terdiri dari kaum bangsawan atau yang mewakili kelompok agama atau institusi tertentu. Demokratisasi dan tumbuhnya kelas sosial baru (kelas menengah), kemudian menuntut perwakilan yang mewakili rakyat umum. Maka lahirlah Majelis Rendah (House of Commons) disamping Majelis Tinggi (House of Lords). Sistem dua kamar di Amerika Serikat, merupakan hasil kompromi antar negara bagian yang berpenduduk sedikit. House of Refresentatives (DPR) mewakili seluruh rakyat. Setiap negara bagian diwakili sesuai dengan jumlah penduduk. Senate (DPD) mewakili negara bagian. Setiap negara bagian di wakili oleh dua orang senator tanpa membeda-bedakan antar negara bagian yang berpenduduk banyak dengan berpenduduk sedikit. Selain hasil kompromi, sistem dua kamar Amerika Serikat, diperkirakan tidak terlepas dari sistem dua kamar.

Negara yang multi etnis yang masyarakatnya memiliki keragaman aspirasi yang memiliki karateristik kewilayahan antara lain nuansa kedaerahan yang cukup kental, lazim mengunakan parlemen dengan istilah dua kamar (bicameral). Kamar pertama lazim disebut majelis rendah dan untuk kamar ke dua disebut mejelis tinggi. Walau kedua kamar masing-masing sama sebagai lembaga parlemen namun keduanya praktis terpisah karena mempunyai misi dan tugas dan mensyaratkan perlunya pemisahan. Bergabungnya dua kamar hanya pada saat terjadinya "hearing" untuk suatu isu atau topik bahasan tertentu namun tidak untuk mengambil keputusan apapun. Dibawah ini penjelasan lebih lanjut akan ke dua lembaga tersebut :

1. Majelis Rendah adalah tempat wakil-waki rakyat mewakili kepentingan partai atas dasar idiologi, konsep atau visi yang skalanya nasional karena objek pertarungan adalah konsep dalam skala nasional maka aktifitas majelis rendah terlibat langsung dengan kegiatan pemerintahan yang dilaksanakan oleh eksekutif, dalam arti langkah atau kebijakan akan cepat ditanggapi atau disorot oleh majelis, baik yang pro maupun yang kontra. Oleh karena fungsi yang demikian, majelis rendah berfungsi sebagai rekan (dalam beberapa hal; dilihat dari kepentingan partai yang memerintah) sekaligus pengawas (dilihat dari kepentingan partai oposisi). Majelis rendah adalah tempat pertama dibahas dan diperdebatkan Rancangan Undangundang (RUU) yang diusulkan oleh Majelis. RUU yang telah disetujui kemudian diajukan ke Majelis Tinggi untuk dibahas dari segi 
kewilyahan, artinya akan ditinjau adakah RUU tersebut bermanfaat bagi wilayah atau malah akan merugikan salah satu wilayah. Dikarenakan kegiatannya yang menyoroti kegiatan eksekutif maka dinamika demokrasi akan lebih dapat dirasakan di Majelis Rendah.

2. Majelis Tinggi adalah majelis tinggi tempat dimana wakil-wakil rakyat membahas, dari sudut kepentingan wilayah, RUU yang diajukan oleh Majelis rendah untuk disetujui atau ditolak.

\begin{tabular}{lll}
\multicolumn{3}{c}{ Perbedaan latar belakang atau } \\
tujuanya yang & hendak dicapai, \\
memepengaruhi & juga cara-cara
\end{tabular} menentukan masing-masing kamar. Bagi Indonesia, ada beberapa pertimbanganpertimbangan menuju sistem dua kamar.

1. Seperti diutarakan Montesqeui, sistem dua kamar merupakan suatu mekanisme cheks and balances antara kamar-kamar dalam satu badan perwakilan.

2. Penyederhanaan sistem badan perwakilan. Hanya ada satu badan perwakilan tingkat pusat yang terdiri dari dua unsur, yaitu unsur yang langsung mewakili seluruh rakyat dan unsur yang mewakili daerah. Tidak diperlukan utusan golongan. Kepentingan golongan diwakili dan disalurkan melalui unsur yang langsung mewakili seluruh rakyat.

3. Wakil daerah menjadi bagian dari pelaksanakan fungsi parlemen (membentuk undang-undang, mengawasi pemerintah, menetapkan APBN, dan lainnya). Dengan demikian segala kepentingan daerah terintegrasi dan dapat dilaksanakan sehari-hari dalam kegiatan parlemen. Hal ini merupakan salah satu faktor untuk menguatkan kesatuan, menghindari disintegrasi.

4. Sistem dua kamar akan lebih produktif. Tugas dan wewenang dapat dilakukan setiap unsur. Tidak perlu menunggu atau bergantung pada satu badan seperti DPR sekarang.
Berkaitan dengan keberadaan dari lembaga perwakilan, penerapannya di beberapa negara memiliki perbedaan variasi. Ada negara yang menganut sistem perwakilan satu kamar, dua kamar dan tiga kamar. Perbedaan yang melekat pada ciri dan sifat dari masing-masing sistem ini memberikan konsekuensi tersendiri terhadap tugas dan kewenangannya. Khusus mengenai sistem parlemen dua kamar, di mana terdiri dari Majelis Rendah (lower House) dan Majelis Tinggi (Upper House). Di antara kedua majelis tersebut memiliki kewenangan yang berbeda satu sama lain. Dalam hal ini, Ni'matul Huda mengemukakan : ${ }^{4}$

"Di beberapa negara, majelis rendah biasanya diberi wewenang untuk mengambil prakarsa mengajukan rencana anggaran dan pendapat negara, sedangkan majelis tinggi berperan dalam pembuatan dan perumusan kebijaksanaan luar negeri. Pada prinsipnya, kedua kamar majelis dalam sistem bicameral itu memiliki kedudukan yang sederajat. Satu sama lain tidak saling membawahi, baik secara politik maupun secara legislatif. Undang-undang tidak dapat ditetapkan tanpa persetujuan bersama yang biasanya dilakukan oleh suatu panitia bersama ataupun melalui sidang gabungan di antara kedua majelis itu".

$\begin{array}{llr}\begin{array}{r}\text { Pada } \\ \text { dibentuknya } \\ \text { dihubungkan }\end{array} & \begin{array}{r}\text { mulanya } \\ \text { parlemen }\end{array} & \begin{array}{r}\text { tujuan } \\ \text { bikameral }\end{array} \\ \end{array}$ dengan bentuk negara federasi yang memerlukan dua kamar majelis. Kedua majelis itu perlu diadakan untuk maksud melindungi formula federasi itu sendiri. Akan tetapi, dalam perkembangannya bersamaan dengan pergeseran kecenderungan ke arah bentuk negara kesatuan. Maka sistem bikameral itu juga dipraktekkan di lingkungan negara-negara kesatuan. Dua alasan utama yang dapat dikemukakan

\footnotetext{
${ }^{4}$ Ni'matul Huda, op cit hal 258-259
} 
penggunaan sistem bikameral ini adalah :

)

1. Adanya kebutuhan akan perlunya suatu keseimbangan yang lebih stabil antara pihak eksekutif dan lagislatif, the unbridled power of a single chamber being restrained by the creation of a Second Chamber recruited on a different basis;

2. Keinginan untuk membuat sistem parlementer berjalan, jika tidak lebih efisien, setidak-tidaknya lebih lancar (smooth), melalui suatu majelis (chamber) yang disebut revising chamber untuk memelihara a careful check on the sometimes hasty decisions of a first Chamber.

Penerapan sistem bikameral itu, dalam prakteknya sangat dipengaruhi oleh tradisi, kebiasaan, dan sejarah ketatanegaraan negara yang bersangkutan. Seperti halnya negara federasi, negara kesatuan juga bertujuan melindungi wilayah tertentu, melindungi etnik, dan kepentingan-kepentingan khusus dari golongan rakyat tertentu (seperti kelompok kepentingan, golongan minoritas, dan sebagainya) dan suara mayoritas (tirani mayoritas). Sebenarnya tidak banyak perbedaan apakah sistem unikameral atau bikameral yang digunakan dalam negara kesatuan atau federasi itu. Penting bahwa sistem majelis tunggal atau ganda itu dapat benar-benar berfungsi untuk menyalurkan aspirasi rakyat dalam mengawasi jalannya pemerintahan. Penerapan dan penggunaan sistem perwakilan dua kamar atau satu kamar dalam beberapa negara di dunia memiliki latar belakang peneran yang berbedabeda. Hal ini dikarenakan oleh berbagai macam faktor yang melingkupinya. Penerapan sistem parlemen ini tergantung pada kebijakan yang berlaku di negara tersebut.

\section{Metode Penelitian}

\section{Tipe Penelitian.}

Tipe penelitian hukum yang dilakukan adalah yuridis normatif (hukum normatif). Metode penelitian hukum normatif adalah suatu prosedur penelitian ilmiah untuk menemukan kebenaran berdasarkan logika keilmuan hukum dari sisi normatifnya. ${ }^{5}$ Oleh karena itu penelitian hukum ini difokuskan untuk mengkaji penelitian hukum tentang kaidah-kaidah atau norma-norma dalam hukum positif, yakni norma hukum yang terkait dengan pembagian kekuasan MPR, DPR dan DPD.

\section{Pendekatan Masalah}

Pendekatan yang dilakukan dalam penelitian ini menggunakan pendekatan perundang-undangan (statue approach). Pendekatan perundang-undangan adalah pendekatan yang dilakukan oleh peneliti melalui aturan perundangundangan yang berkaitan dengan materi yang dibahas yaitu mengenai kekuasan MPR, DPR dan DPR. Selain itu juga digunakan pendekatan Konsep (conceptual approach). Pendekatan konsep digunakan untuk melihat konsep konsep yang terkait pembagian kekuasaan antara MPR, DPR dan DPR dalam rangka mewujudkan kedaulatan rakyat.

\section{Bahan Hukum}

Dalam penulisan sekripsi ini penulis menggunakan bahan-bahan hukum yang meliputi:

a. Bahan hukum primer:

Bahan hukum primer adalah merupakan bahan hukum yang bersifat autoritatif artinya mempunyai otoritas, bahan hukum terdiri dari perundang-undangan, catatan resmi, atau risalah dalam pembuatan perundang-undangan dan putusan hakim. Adapun bahan hukum primer tersebut meliputi: Undang Undang Dasar 1945 (amandemen), Undang Undang Nomor 27 tahun 2009 tentang Majelis Permusyawaratan Rakyat, Dewan Perwakilan Rakyat, Dewan 
Perwakilan Daerah, dan Dewan Perwakilan Rakyat Daerah..

b. Bahan Sekunder:

Bahan hukum sekunder adalah bahan yang diperoleh dari buku teks, jurnal-jurnal, pendapat para sarjana dan kasus-kasus hukum. ${ }^{6}$

\section{Prosedur Pengumpulan Bahan Hukum}

Baik bahan primer maupun bahan hukum sekunder dikumpulkan berdasarkan topik permasalahan yang telah dirumuskan dan diklasifikasi menurut sumber dan hirarkinya untuk dikaji secara komprehensif.

\section{Pengolahan dan Analisis Bahan Hukum}

Adapun bahan hukum yang diperoleh dalam penelitian adalah studi kepustakaan, aturan perundangundangan, yang penulis uraikan dan dihubungkan sedemikian rupa, sehingga disajikan dalam penulisan yang lebih sistematis guna menjawab perumusan masalah yang dirumuskan. Cara pengolahan bahan hukum dilakukan secara deduktif yakni menarik kesimpulan dari suatu permasalahan yang bersifat umum terhadap permasalahan kongkrit yang dihadapi yakni pembagian kekuasaan antara MPR, DPR dan DPD dalam mewujudkan kedaulatan rakyat..

\section{Hasil Penelitian Dan Pembahasan}

1. Pembagian Kekuasaan antara MPR, DPR dan DPD dalam Mewujudkan Kedaulatan Rakyat

Dalam pembukaan Undang-

Undang Dasar Negara Republik Indonesia Tahun 1945 mengamanatkan bahwa susunan negara Republik Indonesia adalah negara yang berkedaulatan rakyat yang dalam pelaksanaannya menganut prinsip

6 Peter Mahmud Marzuki. Penelitian Hukum. Universitas Air Langga. Surabaya. h. 15. kerakyatan yang dipimpin oleh hikmat kebijaksanaan dalam permusyawaratan perwakilan. Untuk mewujudkan hal tersebut perlu dibentuk lembaga permusyawaratan rakyat, lembaga perwakilan rakyat dan lembaga perwakilan daerah yang mampu memperjuangkan aspirasi rakyat termasuk kepentingan daerah dalam rangka menegakkan nilai-nilai demokrasi keadilan dan kesejahteraan rakyat dalam wadah Negara Kesatuan Republik Indonesia. Prinsip kerakyatan yang dipimpin oleh hikmat kebijaksanaan dalam permusyawaratan perwakilan seperti disebutkan dalam penjelasan Undang-Undang Susduk, diwujudkan dengan pembentukan lembaga permusyawaratan yaitu MPR, lembaga perwakilan rakyat yaitu DPR (pusat) dan DPRD (daerah) dan lembaga perwakilan daerah yaitu DPD.

Prinsip kedaulatan rakyat salah satunya tercermin dalam struktur dan mekanisme kelembagaan negara dan pemerintahan yang menjamin tegaknya hukum dan berfungsinya sistem demokrasi. Dari segi kelembagaan, prinsip kedaulatan rakyat itu biasanya diorganisasikan sistem pemisahaan kekuasaan (separation of power) atau pembagian kekuasaan (distribution atau division of power).

Pembagian kekuasaan antara MPR, DPR dan DPD secara prinsipil bertugas untuk mengemban amanat rakyat, sebagai perwujudan kedaulatan rakyat. Sebelum amandemen UndangUndang Dasar RI Tahun 1945 pembagaian kekuasaan yang dianut adalah bersifat vertikal, yaitu MPR sebagai pemegang kedaulatan memberikan dan membagikan kekuasaan yang dimilikinya kepada lembagalembaga negara lainnya. Namun sekarang, dengan kedudukan MPR yang bukan lagi sebagai lembaga tertinggi melainkan sederajat, pembagian kekuasaannya adalah bersifat horizontal. Pembagian kekuasaan antara ketiga lembaga ini, sangat menentukan terwujudnya kepentingan rakyat dengan baik dan proporsional. Kepentingan rakyat adalah pertimbangan yang 
fundamental dalam menjalankan tugas dan fungsi dari masing-masing lembaga negara, sehingga harapan-harapan dari masyarakat dapat terwujud.

Meskipun pada prinsipnya ketiga lembaga ini bekerja dalam rangka kepentingan nasional suatu masyarakat dan sekalipun tidak ada perbedaan dalam hal tujuan yang hendak dicapai secara nasional tetapi dalam rangka efektivitas pencapaian dari maksud dan tujuan pembentukan daripada lembaga-lembaga ini, pembagian kekuasaan antara keduanya harus dijalankan.

Salah satu maksud dan tujuan diadakannya pembagian kekuasaan ini adalah agar terjadi check and balance antara lembaga-lembaga negara untuk saling mengimbangi dan mengawasi dalam kesederajatan yang sebenarnya berdasarkan tugas dan fungsi masingmasing.

Pada intinya, prinsip-prinsip pemisahan atau pembagian kekuasaan di maksudkan untuk membatasi kekuasaan negara dari kemungkinan tindakan sewenang-wenang penguasa. Pengaturan dan pcmbatasan kekuasaan itulah yang menjadi ciri konstitusionalisme dan sekaligus tugas utama konstitusi, sehingga kemungkinan kesewenangwenangan kekuasaan dapat dikendalikan dan diminimalkan. Dalam pengaturan kekuasaan MPR, DPR dan DPD termasuk tugas dan fungsi masingmasing, masih memiliki kecenderungan untuk terjadinya beberapa permasalahan, berupa tindakan sewenang-wenang penguasa.

Permasalahan yang terjadi antara MPR dan DPR. misalnya dalam hal pemberhentian Presiden dan/atau Wakil Presiden. Berdasarkan ketentuan Pasal 3 amandemen Undang-Undang Dasar RI Tahun 1945, kewenangan untuk memberhentikan Presiden dan/atau Wakil Presiden diberikan kepada MPR. Berdasarkan Pasal 6 amandemen Undang-Undang Dasar RI Tahun 1945 DPR hanya berhak untuk mengajukan usul kepada Mahkamah Konstitusi, dan kemudian mengajukan pemberhentian Presiden dan/atau Wakil Presiden kepada MPR (Pasal 7B amandemen Undang-
Undang Dasar RI Tahun 1945), setelah melewati sidang istimewa MPR. Jika DPR benar-benar berniat untuk menjatuhkan Presiden dan/atau Wakil Presiden, cukup ketika Mahkamah Konstitusi mengatakan bahwa Presiden dan/atau Wakil Presiden bersalah, sudah bisa dipastikan Presiden dan/atau Wakil Presiden tersebut bisa dijatuhkan (impeachment).

Hal ini dimungkinkan karena jumlah angguta DPR yang berjumlah 550 orang dapat dipastikan mampu memberhentikan Presiden dan/atau Wakil Presiden, meskipun di dalam MPR masih terdapat DPD yang jumlah anggotanya tidak lebih dari $1 / 3$ anggota DPR (183) orang. Kecuali jika terjadi tawar menawar politik antara DPR dengan Presiden dan/atau Wakil Presiden, atau jumlah suara mayoritas DPD mendukung jumlah suara DPR yang tidak menyetujui impeachment terhadap Presiden.

Hal tersebut tidak memperlihatkan adanya pembagian kekuasaan dalam pengertian yang sebenarnya. Kenyataan ini tentunya dapat menimbulkan terjadinya kecenderungan politik dan tindakan sewenang-wenang oleh DPR terhadap Presiden dan/atau Wakil Presiden.

Berkaitan dengan masalah kedaulatan rakyat, pengaturan antara DPR dan DPD, dapat dilihat dalam pengertian perwakilan yang diemban oleh masing-masing lembaga ini. Makna perwakilan daerah yang diemban oleh DPD kurang melekat. Beberapa kewenangan yang semestinya menjadi kedaulatan rakyat dalam pengertian perwakilan dari masyarakat daerah yang diemban oleh DPD telah berubah fungsi menjadi perwakilan politik sebagaimana sifat perwakilan yang terdapat di dalam DPR. Padahal berdasarkan ketentuan Pasal 27C ayat (1) amandemen UUD 1945 disebutkan : "Anggota Dewan Perwakilan Daerah dipilih dart setiap provinsi melalui pemilihan umum". Selanjutnya dalam ketentuan Pasal 271 Undang-undang Nomor 27 Tahun 2009 disebutkan, "DPD terdiri atas wakil daerah provinsi yang dipilih melalui 
pemilihan umum". Pasal 277 UU 27 Tahun 2009 disebutkan, "Anggota DPD dari setiap provinsi ditetapkan sebanyak empat orang". Ketentuan ini secara jelas menentukan bahwa DPD adalah wakil dari daerah. Sedangkan pemilihan daripada anggota DPR berdasarkan ketentuan Pasal 19 ayat (1) amandemen UUD 1945 disebutkan, "Anggota Dewan Perwakilan Rakyat dipilih melalui pemilihan umum". Dalam ketentuan Pasal 67 Undang-undang Nomor 27 Tahun 2009 disebutkan, " DPR terdiri dari atas anggota partai politik peserta pemilihan umum yang dipilih melalui pemilihan umum".

2. Hubungan antara MPR, DPR dan DPD dalam Sistem Ketatanegaraan Setelah Amandemen UUD 1945

Hubungan antara MPR, DPR, dan DPD adalah hubungan kesederajatan untuk dapat saling mengisi dan mengimbangi, sebagaimana prinsip check and balances. Berdasarkan prinsip ini diharapkan pelaksanaan dari masingmasing tugas dan fungsi yang dimilikinya, dapat lebih membentuk suatu lembaga yang harmonis. Harmonisasi hubungan antara lembaga negara sangat menentukan kualitas dari produk kerja dan kredibilitas daripada lembaga-lembaga negara.

Hubungan antara MPR dengan DPR dan DPD menyangkut bidang tugas yang dijalankan oleh MPR, di mana anggota-anggota DPR dan DPD yang merupakan anggota MPR secara otomatis ikut terlibat didalamnya, seperti dalam kewenangan MPR untuk melantik dan memberhentikan Presiden dan/atau Wakil Presiden serta mengubah dan menetapkan Undang-Undang Dasar RI Tahun 1945. Namun terhadap bidang tugus yang dimiliki oleh DPR maupun DPD maka MPR tidak memiliki kapasitas untuk ikut terlibat, karena MPR tidak memiliki organ tersendiri seperti DPR dan DPD.

Bagaimanakah hubungan antara DPR dan DPD dalam konteks lembaga perwakilan ? Hubungan antara kedua lembaga perwakilan ini dapat dilihat dari fungsi utamanya dalam bidang pengawasan, legislasi dan anggaran. Sebagai sama-sama lembaga parlemen, keseluruhan fungsi parlemen itu ada di kedua lembaga ini, dan karena itu pembagian tugas keduanya dapat diatur berkenaan dengan aspek-aspek tertentu yang terkait dengan fungsi legislatif, pengawasan dan fungsi anggaran tersebut. Misalnya, pelaksanaan fungsi legislatif, pengawasan dan fungsi anggaran yang berkenaan dengan kepentingan daerahdaerah, haruslah dilakukan oleh DPD bukan oleh DPR.

Hubungan antara DPR dan DPD dalam bidang legisiasi, berdasarkan amandemen Undang-Undang Dasar RI Tahun 1945, terlebih dahulu dipaparkan mengenai kekuasaan dari masing-masing lembaga perwakilan tersebut berkenaan dengan fungsi pembuatan undangundang (legisiasi).

Dewan Perwakilan Rakyat memiliki kekuasaan untuk membentuk undang-undang. Setiap rancangan undang-undang yang diajukan oleh Presiden, DPR maupun DPD, kemudian dibahas oleh Presiden dan DPR untuk mendapat persetujuan bersama. Jika rancangan undang-undang itu tidak mendapat persetujuan bersama, RUU itu tidak boleh diajukan lagi dalam persidangan DPR masa itu. Rancangan undang-undang yang telah disetujui bersama untuk menjadi undang-undang kemudian disahkan oleh Presiden. Apabila presiden tidak mengesahkan RUU yang telah disetujui bersama, untuk menjadi undang-undang kemudian disahkan oleh Presiden. Apabila Presiden tidak mengesahkan RUU yang telah disetujui bersama, dalam waktu tiga puluh hari semenjak RUU tersebut disetujui, RUU itu sah menjadi undangundang.

Sedangkan kekuasaan Dewan Perwakilan Daerah dalam bidang legisiasi, dimana DPD mengajukan kepada DPR RUU yang berkaitan dengan otonomi daerah, hubungan pusat dan daerah, pembentukan pemekaran serta penggabungan daerah, pengelolaan sumber daya alam dan sumber daya ekonomi lainnya, serta yang berkaitan dengan perimbangan keuangan pusat dan 
daerah. DPD ikut membahas RUU yang berkaitan dengan otonomi daerah, hubungan pusat dan daerah, pembentukan, pemekaran dan penggabungan daerah, pengelolaan sumber daya alam dan sumber daya ekonomi lainnya, serta perimbangan keuangan pusat dan daerah, memberikan pertimbangan kepada DPR atas RUU APBN dan RUU yang berkaitan dengan pajak, pendidikan dan agama.

Kekuasaan DPD dalam bidang legislasi di bandingkan dengan kekuasaan DPR, hanya terbatas pada kekuasaan untuk mengajukan RUU dan bukan memberikan persetujuan. Kemampuan uutuk memberikan persetujuan terhadap setiap RUU menurut amandemen Undang-Undang Dasar RI Tahun 1945 hanya diberikan kepada DPR dan Presiden. Bukankah sebagai suatu lembaga perwakilan yang memang memiliki tugas untuk membentuk UU seharusnya memiliki kekuasaan untuk membentuk dan sekaligus memberikan persetujuan terhadap pembuatan suatu RUU untuk menjadi UU. Kekuasaan yang dimiliki oleh Presiden untuk memberikan persetujuan terhadap RUU menjadi UU, sebaiknya dihapuskan saja, karena Presiden selaku lembaga eksekutif hanyalah pelaksana daripada UU yang dibuat oleh lembaga perwakilan. Namun persoalan ini tentunya tidak bisa dilepaskan dari dianutnya sistem "soft becameralism" di Indonesia dan bukan "strong becameralism".

Dalam sistem parlemen dua kamar seperti di Amerika Serikat, setiap rancangan UU mengharuskan persetujuan bersama antara DPR dan Senat. Ketentuan semacam ini tentu tidak harus diadopsi secara persis dalam situasi di Indonesia. Jika suatu RUU dipersyaratkan untuk disetujui oleh DPR dan DPD sekaligus seperti di Amerika Serikat, niscaya dapat timbul penilaian bahwa proses pembuatan suatu UU di masa yang akan datang menjadi lebih berat, yaitu di samping harus disetujui bersama oleh DPR. dan DPD, juga harus disetujui bersama oleh Presiden. ${ }^{7}$

Terhadap hal ini Jimly Asshiddiqie mengusulkan agar persetujuan atas RUU sebaiknya disetujui oleh dua lembaga saja, yaitu DPR bersama Presiden, atau DPR bersama DPD. Jika dua dari ketiga lembaga tersebut sudah menyetujui maka lembaga ketiga tidak dapat lagi menolak untuk menerimanya sebagai UU yang sah. Sayang, dalam naskah perubahan Undang-Undang Dasar RI Tahun 1945, khususnya yang berkenaan dengan ketentuan Pasal 20 ayat (1) sampai dengan ayat (5), pengertian demikian belum tercakup secara utuh. ${ }^{8}$

Berkaitan dengan itu, mengenai hubungan kekuasaan antara DPR dan DPD dalam bidang legislasi yang mana DPD hanya memiliki kekuasaan untuk mengajukan usul dan membahas usulannya tersebut bersama-sama dengan DPR dan pemerintah, tetapi hanya sampai pada tingkat I dalam hal penyampaian pandangan dan pendapat DPD atas RUU, serta tanggapan atas pandangan dan pendapat dari masingmasing lembaga. Pandangan dan pendapat serta tanggapan ini dijadikan sebagai bahan masukan utuk pembahasan lebih lanjut antara DPR dan pemerintah.

Keterlibatan DPD yang hanya sampai pada tingkat I, dan pada tingkatan selanjutnya dibahas bersama oleh DPR bersama-sama dengan pemerintah, memberikan kemungkinan atas usul RUU dari DPD tersebut tidak mendapat persetujuan dari pemerintah dan DPR. Sebagaimana diketahui bahwa pemerintah memiliki hak veto (Pasal 20 ayat (3) amandemen Undang-Undang Dasar RI Tahun 1945). Demikian pula halnya dengan penolakan yang bisa saja muncul dari DPR pada saat pembahasan antara DPR dengan pemerintah.

Pertimbangan ini, meskipun menurut ketentuan amandemen Undang-

\footnotetext{
${ }^{7}$ Jimly Ashiddiqie. Op cit hal 18
}

8 Jimly Ashiddiqie. Op cit hal 18 
Undang Dasar RI Tahun 1945 dan UU No. 27 Tahun 2009 harus ditindak lanjuti oleh DPR dan pemerintah (Presiden), sifatnya kurang mengikat. Kurangnya kekuatan mengikat dari sifat pertimbangan yang dimiliki oleh DPD ini dapat saja "disepelekan" oleh DPR maupun oleh pemerintah. Maksud "disepelekan" di sini adalah meskipun pada pembahasan nantinya usulan dan pertimbangan DPD ini akan dilampirkan, namun tidak terlalu mempengaruhi dalam pengambilan keputusan dalam pembahasan sebuah rancangan undangundang. Apabila DPR dan pemerintah tidak menjadikan masukan dari DPD yang dihasilkan pada pembahasan tingkat I tersebut, hal ini merupakan konsekuensi tersendiri yang bisa saja terjadi, karena hak yang dimiliki oleh DPR dan pemerintah.

\section{E. Penutup}

\section{Kesimpulan}

a. Pembagian kekuasaan antara MPR, DPR dan DPD belum begitu optimal dalam mewujudkan sistem ketatanegaran yang berkedaulatan rakyat. Hal ini terjadi karena struktur kekuasaan parlemen yang dimiliki bersifat tiga kamar jika dilihat dari kekuasaan yang dimiliki oleh masing-masing lembaga perwakilan. Selain itu, belum optimalnya pelaksanaan kedaulatan dalam pembagian kekuasaan di Indonesia juga disebabkan kerena kekuasaan DPR masih jauh lebih besar dan lebih luas dibandingkan dengan kekuasaan yang dimiliki DPD. Dengan kecilnya kekuasaan yang dimiliki oleh DPD berarti tingkat perwakilan yang lebih mendekatkan pada prinsip kedaulatan rakyat tentunya tidak maksimal untuk dijalankan dan dilaksanakan berdasarkan inisiatif dari DPD sendiri. Sifat perwakilan yang dijalankan oleh DPD tidak tercermin secara penuh dalam pengaturannya. Hal demikian karena sifat parlemen yang diadopsi oleh Indonesia sejak adanya perubahan Undang-Undang Dasar RI Tahun 1945 bersifat soft bicameral dan bukan strong bicameral.

b. Hubungan antara MPR, DPR dan DPD amandemen Undang-Undang Dasar RI Tahun 1945, yang dimaksud untuk lebih saling mengisi dan mengawasi sebagai prisnsip cheks and balances, seringkali menimbulkan dampak yang tidak sesuai dengan prinsip keberadaan dari ketiga lembaga tersebut. Meskipun hubungan antara MPR, DPR dan DPD tidak terlalu menimbulkan permasalahan, akan tetapi permasalahan yang terjadi dari bentuk hubungan antara ketiga lembaga tersebut telah memberikan kemungkinan terjadinya kecenderungan "super power" dari DPR dan DPD. Maka perwakilan yang diemban oleh kedua lembaga tersebut dalam hubungannya memungkinkan terjadinya hubungan yang tidak harmonis. Hal ini diakibatkan karena makna perwakilan yang diemban oleh DPD tidak sesuai dengan prinsip dan keterwakilan yang dihasilkan dari pemilu sebagai wakil daerah. Dengan demikian maka cheks and balances yang seharusnya dijalankan dalam rangka untuk mewujudkan system ketatanegaraan yang imbang (kesederajatan) dan saling mengawasi masih jauh dari harapan.

\section{Saran}

Masih perlu adanya perubahan pengaturan tentang hal-hal yang berkenaan dengan DPD, karena sesuai dengan perkembangannya masyarakat yang mengarah pada tingkat kemandirian daripada daerah-daerah seiring dengan diterapkannya otonomi daerah.

Perlu dibuat sebuah kode etik yang memungkinkan dapat mencegah terjadinya konflik antara DPR dengan DPD dan perlu adanya instrument hukum yang mampu melandasi kinerja daripada DPR dan DPD pada masa yang akan datang sehingga peran daripada masingmasing lembaga ini dapat sesuai dengan keterwakilan yang dimiliki. 
Adanya perimbangan kewenengan antara pusat dan daerah, karena yang selama ini terjadi segala sesuatu hal yang berkenaan dengan kebijakan daerah haruslah mendapat restu dari pusat. Sebaliknya DPR, tidak harus mendapat persetujuan terlebih dahulu dari DPD dalam melaksanakan tugasnya. Sehinga terjadi ketimpangan kewenangan antara pusat dan daerah agar tercipta checks and balances.

Dan yang terakhir adalah perlunya kesadaran dari DPR untuk selalu mengikut sertakan pertimbanganpertimbangan yang diajukan oleh DPD sehingga makna keterwakilan yang dimiliki oleh DPD dapat lebih terwarnai dalam penerapannya.

\section{DAFTAR PUSTAKA}

\section{LITERATUR:}

Adnan Buyung Nasution. Telaah Akademis Terhadap Materi Undang-undang Dasar yang akan Datang. Seminar diselengarakan oleh BPHN, 9-10 Oktober 2001.

Azhary. Negara Hukum Indonesia Analisis Yuridis Normatif Tentang UnsurUnsurnya, UI Press, Jakarta, cetakan pertama, 1995.

CST. Kansil dan Christine ST. Kansil, Hukum Tata Negara Republik Indonesia 1,
Rineka Cipta, Jakarta, cetakan ketiga, 2000.

Dahlan Thaib, Kedaulatan Rakyat, Negara Hukum dan Konstitusi, Liberty. Yogyakarta. Cetakan kesatu, 1999.

, DPR Dalam Sistem Ketatanegaraan Indonesia, Yogyakarta ; Liberty, Edisi kedua. Cetakan pertama. 2000.

Dahlan Thaib, Jazim Hamidi, Ni'matul Huda, Teori dan Hukum Konstitusi, PT. RajaGrafindo, Jakarta, 2001

Ismail Suny, Pergeseran Kekuasaan Eksekutif suatu Penyelidikan dalam Hukum Tatanegara, Aksara Baru, Jakarta 1986.

Jimly Asshidiqie. Format kelembagaan Negara dan Pergeseran Kekuasaan dalam UUD 1945. Yogyakarta : FH UII Press. 2004.

Johnny Ibrahim, Teori \& Metode Penelitian Hukum Normatif, Banyumedia Publishing, Malang 2006.

Miriam Budiardjo. Dasar-dasar Ilmu Politik. Jakarta : PT. Gramedia Pustaka Utama. 2001.

Moh. Mahfud MD. Hukum dan Pilar-pilar Demokrasi, Gama Media, Yogyakarta, 1999.

Peter Mahmud Marzuki. Penelitian Hukum. Universitas Air Langga. Surabaya.

PERATURAN PERUNDANG UNDANGAN:

Undang Undang Dasar 1945

Undang Undang Nomor 27 Tahun 2009 tentang Majelis Permusyawaratan Rakyat, Dewan Perwakilan Rakyat, Dewan Perwakilan Daerah, dan Dewan Perwakilan Rakyat Daerah. 